Dept. of Poultry Diseases,

Faculty of Veterinary Medicine, Beni-Suef University.

\title{
THE PREVALENCE OF SUBCLINICAL INFECTIOUS BURSAL DISEASE IN COMMERCIAL BROILER FLOCKS
}

(With 5 Tables and 5 Figures)

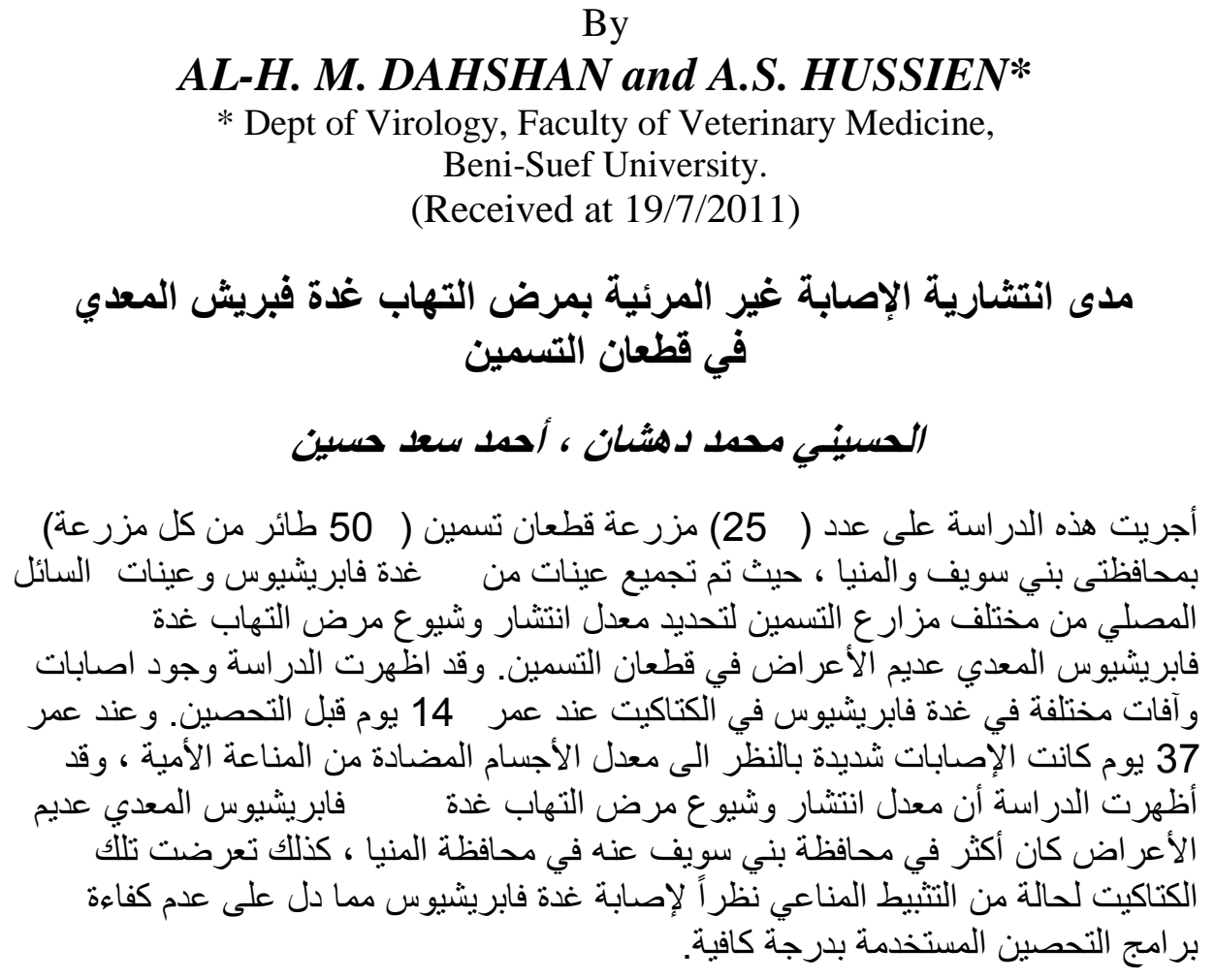

\section{SUMMARY}

This study was conducted on twenty broiler farms located in Beni-Suef and El Minia Governorates during November and December 2009. Fifty birds from each farm were subjected to investigation. Bursae and serum samples were collected. On the basis of lesions of IBD as bursal atrophy, including lymphoid necrosis, stromal edema, and infiltrates of heterophils and macrophages, were first detected in Bursae of Fabricius at 14 days of age and before vaccination. At 37 days, all Bursae of Fabricius had lesions characteristic of IBD, including severe lymphoid 
depletion, proliferation of epithelial cells, and mild fibroplasia. Although mean maternal antibody levels which estimated by enzyme-linked immunosorbent assay (ELISA)in broilers were apparently protective through day 13, IBD antibodies decreased to non protective levels (below 1,000 ) by day 15 to 22 . Titers began to increase by day 27 to 34 because of field exposure. The prevalence of IBD was $81.5 \%$ and $71.1 \%$ in Beni-Suef and El Minia respectively. Highest prevalence was found in Beni-Suef and lowest was found in El Mina. The study also showed that the broilers of two weeks of age were subjected to immunosuppression due to bursal damage and suggested that the existing vaccination programs were not effective.

Key words: IBD, subclinical infection, immunosuppression, ELISA test, serum antibodies

\section{INTRODUCTION}

Infectious bursal disease (IBD) is an acute, highly contagious disease of young chicks. It is caused by a dsRNA virus belongs to member of the genus Avibirnavirus of the family Birnaviridae (Lukert and Saif 1997; Kibenge et al., 1988; Muller et al., 2003). IBDV has a worldwide distribution, occurring in all major poultry producing areas (Wit and William Baxendale, 2004). Infectious Bursal Disease Virus (IBDV) produces two distinctly different disease symptoms namely the clinical form and the subclinical form in susceptible chickens depending on age at infection. Clinical and subclinical infection with IBDV may cause immunosuppression (Sharma et al., 2000; Ahmed and Akhter, 2003; Uddin and Hossain, 2006). The virus can infect turkeys, ducks, guinea fowl and ostriches but the clinical disease occurs in chickens mainly young birds are clinically affected. Severe acute disease of 3-6week-old birds is associated with high mortality, but a less acute or subclinical disease is common in 0-3-week-old birds. This can cause secondary problems due to the effect of the virus on the bursa of Fabricius. IBD virus (IBDV) causes lymphoid depletion of the bursa, and significant depression of the humoral antibody response if occurs at the first 2 weeks of life, may result. Two distinct serotypes of infectious bursal disease virus (IBDV) are known to exist. Serotype 1 virus causes clinical disease in chickens younger than 10 weeks. Older chickens usually show no clinical signs. Serotype 2 antibodies are very widespread in turkeys and are sometimes found in chickens and ducks. 
There are no reports of clinical disease caused by infection with Serotype 2 virus (Lasher and Shane, 1994). IBD continues to be the most serious Problem that contributes to major economic losses in poultry farming world wide. Breed variation in disease Susceptibility has already been shown for IBDV and many other diseases of poultry (Bumstead et al., 1991; Hassan et al., 2004), and it is clear that a range of different genes affect susceptibility to different diseases. Recently, it was suggested that overall immune competence can be improved by line selection for high antibody response of young chicks to controlled immunization with a single antigen (Yunis et al., 2002). Passively acquired antibodies have been shown to protect chickens from IBDV (Corley et al., 2002; Fahey et al., 1989). The titers of antibodies in the circulation correlate with the efficacy of vaccination.

This study was carried out to investigate the prevalence of subclinical infectious bursal disease in commercial broiler flocks located in Beni-Suef and El Minia Governorates during November and December 2009.

\section{MATERIALS and METHODS}

\section{1 - General examination:}

General examination was carried out to observe any visible abnormality, general condition of the chicken (50 bird for each farm) and each bird was weighted

\section{2 - Postmortem examination:}

Postmortem examination was conducted with the help of rubber gloves, a pair of shears, scissors, knife, scalpel and forceps. The bursa of Fabricius was located by opening the cloaca, laid on its distal side and was examined.

\section{3 - Sample collection and preparation of bursa of Fabricius collected from various farms.}

Bursal samples were collected and weighted, body weight was determined before scarifying of chicks. Bursa/body weight ratio, bursal index and bursa/ body weight index were calculated according to Sharma et al. (1989) as following:

- Bursa: body weight ratio = bursa weight/body weight.

- Bursal index = Bursa: body weight ratio X 1000.

- Bursa: body weight index =

Bursa: body weight ratio of infected chicks

Mean bursa: body weight ratio of control chicks 
Chicks with bursa: body weight index lower than 0.7 was considered suffering from bursal atrophy. (Lucio and Hitchner 1979) the bursae chilled as quickly as possible and stored in frozen state for further processing. Tissue specimens from bursa were fixed in $10 \%$ neutral formaline, dehydrated in grade alcohol, cleared with xylene and embedded in paraffin. Section of an average thickness of 5 microns was stained with hematoxyline and eosin (H\&E) according to Culling (1974). The severity of the bursal lymphoid lesions was scored 0-5 on the basis of lymphoid necrosis and /or depletion as well as intrafollicular fibrosis according to Muskett et al. (1979) as the following:

* 0---- no damage (normal).

* 1---- 5-25\% of lymphoid follicles (per field) affected, mild necrosis.

* 2---- 25-50\% of lymphoid follicles (per field) affected, moderate generalized lymphocytes depletion.

* 3---- 50-75\% of lymphoid follicles (per field) affected, severe lymphocytes depletion.

* 4---- more than $75 \%$ of lymphoid follicles (per field) affected few lymphocytes and increased connective tissue, cyst and thickened corrugated epithelium.

* 5---- over $75 \%$ to $100 \%$ follicular damage and fibroplasias.

\section{4 - Serum samples:}

2000 blood samples (1000 at 20 days of age and 1000 at the 37 days of age) were collected from different commercial broiler farms from BeniSuef and El Minia Governorates in clean dry, sterile wesserman tubes. Serum samples were carefully separated in a small Eppendorf vials, all the serum samples were heat inactivated at $56^{\circ} \mathrm{C}$ for $25-30$ minutes in a water bath and then processed for laboled and kept at $-20^{\circ} \mathrm{C}$ till used in ELIZA.

\section{5 - Experimental chicks:}

200 chicks were obtained from Al-Azab project for poultry production, Fayoum. Dam hens of native breeds were aged 22 weeks and received oil IBD vaccine at 18 weeks of age. These chicks were floor reared under natural day light in previously cleaned and disinfected rooms and feed on balanced commercial ration.

6 - IBD ELISA Kits:

IBDV-ELISA Kits were obtained from Kikegaard and Perry laboratories (Kpl), U.S.A. 


\section{7 - ELISA test procedures:}

ELISA test was carried out according to manufactural instructions as while

\section{Calculation of ELISA titers:}

- Negative control mean $(\mathrm{NCx})=$ well $\frac{\mathrm{A} 1+\text { well } \mathrm{A} 2}{2}=\mathrm{NCx}$

- Positive control mean $(\mathrm{PCx})=\frac{\text { well A3+ well A4 }}{2}=\mathrm{PCx}$

- $\mathrm{S} / \mathrm{P}$ ratio $\quad=\underline{\text { sample mean }-\mathrm{NCx}=\mathrm{S} / \mathrm{P}}$

$$
\mathrm{PCx}-\mathrm{NCx}
$$

- Titer- Relates $\mathrm{S} / \mathrm{P}$ at a 1:500 dilution to an endpoint titer: $\log 10$ titer $=1.09(\log 10 \mathrm{~S} / \mathrm{P})$

\section{8 - Statistical analysis:}

Statistical Analysis of variance (ANOVA) test was used to estimate differences among treatments according to Steel and Torrie (1960). Correlation and linear regression analysis were also performed using Microsoft excel program.

\section{RESULTS and DISSCUSION}

Suspected chickens were subjected to postmortem pathological examination; the gross lesions were noted on different parts of body, especially on bursa of Fabricius for confirmation of IBD. Gross pathological lesions observed on postmortem examination, the principal lesion was found on the $\mathrm{BF}$, areas of necrosis were present and the $\mathrm{BF}$ shrank to half of its normal

The overall prevalence of subclinical IBD in broiler chickens was $81.5 \%$ and $71.1 \%$ (Table 1 and 2) in Beni-Suef and El Minia respectively and the most susceptible age for IBD was concluded to be 2nd week. The present study showed that out of 1000 broiler birds, 917 were affected at 2 nd week of age with the highest prevalence $(71.9 \%)$ of IBD. Similar reports have been described by (Hirai et al., 1981) who reported that susceptibility of chickens to IBD is influenced by their age reaching a peak at 4 weeks of age. The infected chicks had severed reduction in the bursa/body weight ratio, index and bursal index compared with control non-infected chicks. The bursa/body weight indices of the infected chicks were 0.50 in Beni-Suef and El Minia Governorates (Table 3 and 4). At 25 days of age the bursa lesion score 
was (1) the Bursae showed moderate histopathological changes represented by lymphocytic cell necrosis with depletion and decrease in the size of lymphoid follicles, in addition to slight proliferation in the intrafollicular fibrous connective tissue (i.e.fibroplasia) more than $50 \%$ of follicles damaged (score 3 ).

Table 1: Prevalence of infectious bursal disease in broiler chickens in different age in Beni-Suef

\begin{tabular}{|c|c|c|c|}
\hline $\begin{array}{c}\text { Age of birds } \\
\text { (days) }\end{array}$ & $\begin{array}{c}\text { Total number of } \\
\text { Birds }\end{array}$ & $\begin{array}{c}\text { No. of infected } \\
\text { birds }\end{array}$ & $\begin{array}{c}\text { Percentage of infection } \\
\text { (prevalence) }\end{array}$ \\
\hline 14 & 500 & 335 & $67 \%$ \\
\hline 37 & 500 & 480 & $96 \%$ \\
\hline total & 1000 & 815 & $81.5 \%($ mean $\%)$ \\
\hline
\end{tabular}

Table 2: Prevalence of infectious bursal disease in broiler chickens in different age in El Minia

\begin{tabular}{|c|c|c|c|}
\hline $\begin{array}{c}\text { Age of birds } \\
\text { (days) }\end{array}$ & $\begin{array}{c}\text { Total number of } \\
\text { Birds }\end{array}$ & $\begin{array}{c}\text { No. of infected } \\
\text { birds }\end{array}$ & $\begin{array}{c}\text { Percentage of infection } \\
\text { (prevalence) }\end{array}$ \\
\hline 14 & 500 & 384 & $76.8 \%$ \\
\hline 37 & 500 & 477 & $65.4 \%$ \\
\hline total & 1000 & 861 & $71.1 \%$ (mean \%) \\
\hline
\end{tabular}

Table 3: Mean Bursa weight, bursa/body weight index and bursal index in Beni-Suef.

\begin{tabular}{|c|c|c|c|c|}
\hline Age(days) & Body W. & Bursa W. & Bursal index & B/B.W.index \\
\hline 14 & $382 \pm 35$ & $0.33 \pm 0.18$ & $0.86 \pm 0.38$ & $0.45 \pm 0.14$ \\
\hline control & $433 \pm 102$ & $0.86 \pm 0.20$ & $0.19 \pm 0.08$ & \\
\hline 37 & $1830 \pm 209$ & $0.26 \pm 0.08$ & $0.14 \pm 0.07$ & $0.50 \pm 0.16$ \\
\hline control & $1973 \pm 102$ & $0.56 \pm 0.17$ & $0.28 \pm 0.11$ & \\
\hline
\end{tabular}


Table 4: Mean Bursa weight, bursa/body weight index and bursal index in El Minia.

\begin{tabular}{|c|c|c|c|c|}
\hline Age(days) & Body W. & Bursa W. & Bursal index & B/B.W.index \\
\hline 14 & $345 \pm 35$ & $0.29 \pm 0.18$ & $0.84 \pm 0.40$ & $0.50 \pm 0.16$ \\
\hline control & $489 \pm 102$ & $0.66 \pm 0.20$ & $0.13 \pm 0.04$ & \\
\hline 37 & $1750 \pm 216$ & $0.25 \pm 0.14$ & $0.14 \pm 0.06$ & $0.51 \pm 0.15$ \\
\hline control & $1890 \pm 212$ & $0.43 \pm 0.17$ & & \\
\hline
\end{tabular}

Table 5: Mean ELISA titers of IBDV maternal antibody of broiler chickens in different ages.

\begin{tabular}{|c|c|c|}
\hline $\begin{array}{c}\text { Age of birds } \\
\text { (days) }\end{array}$ & $\begin{array}{c}\text { Mean ELISA titers } \\
\text { (Beni-Suef) }\end{array}$ & $\begin{array}{c}\text { Mean ELISA titers } \\
\text { (El Minia) }\end{array}$ \\
\hline 14 & $904 \pm 298$ & $890 \pm 118$ \\
\hline 37 & $3544 \pm 272$ & $3965 \pm 388$ \\
\hline
\end{tabular}

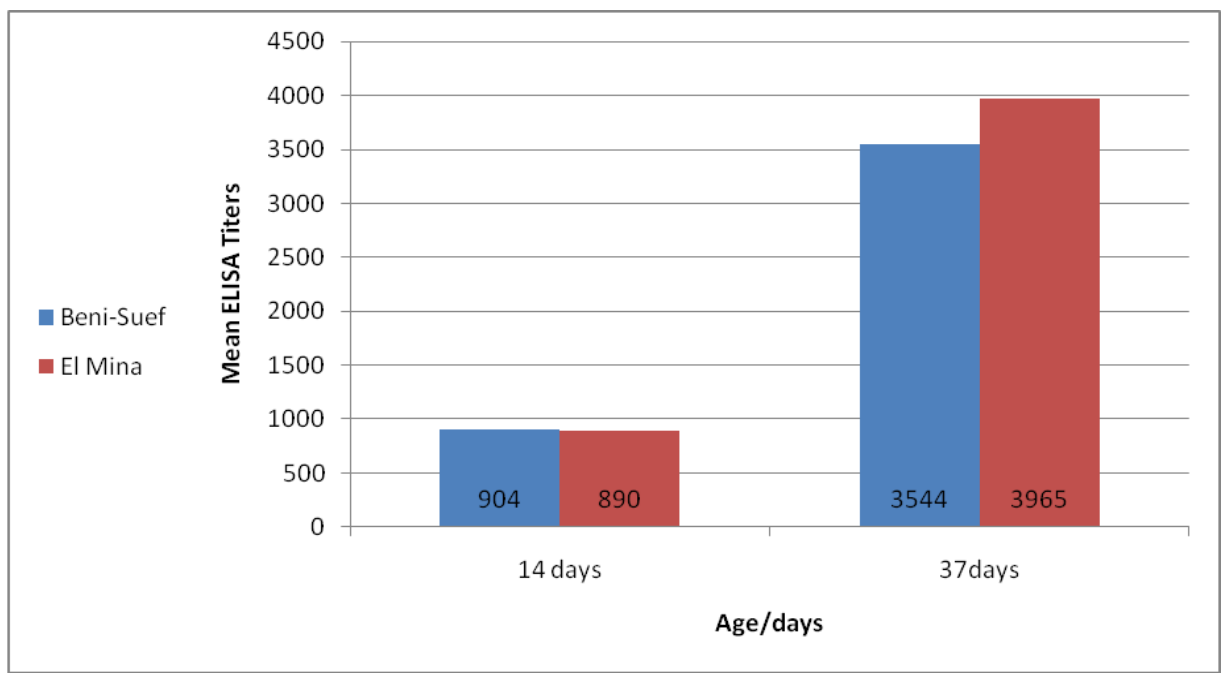

Fig. 1: Mean ELISA titers of IBDV maternal antibody of broiler chickens in different ages 


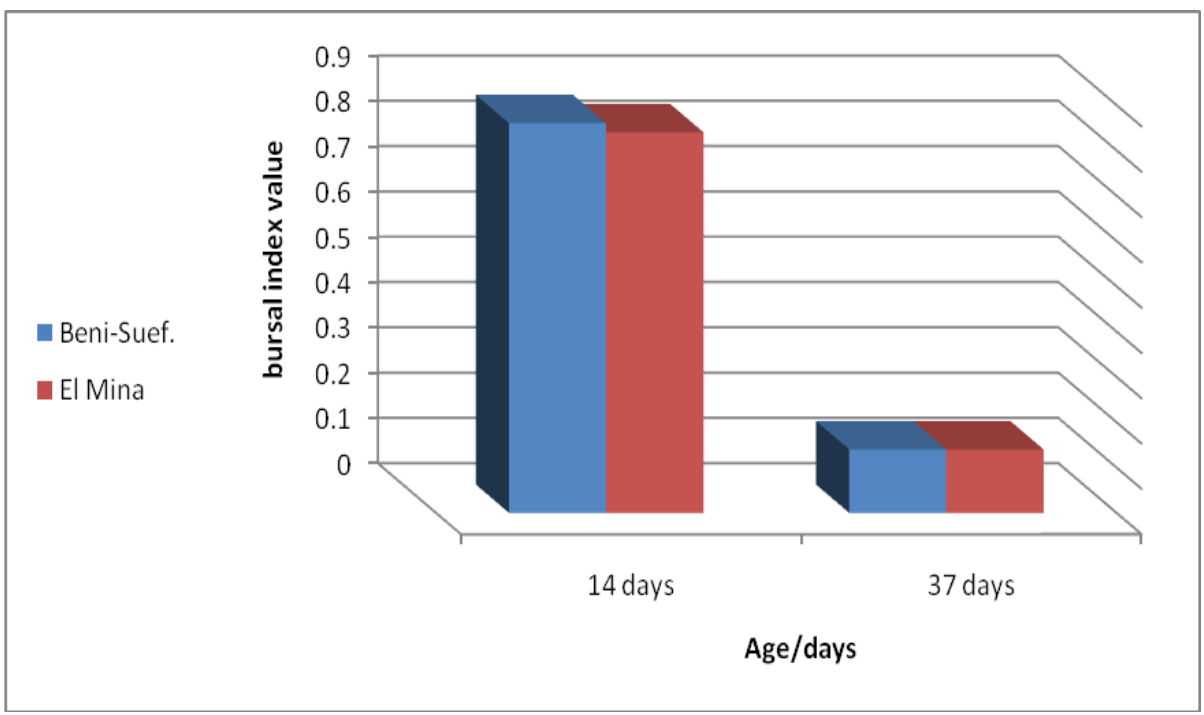

Fig. 2: Mean bursal index values in Beni-Suef and El Minia

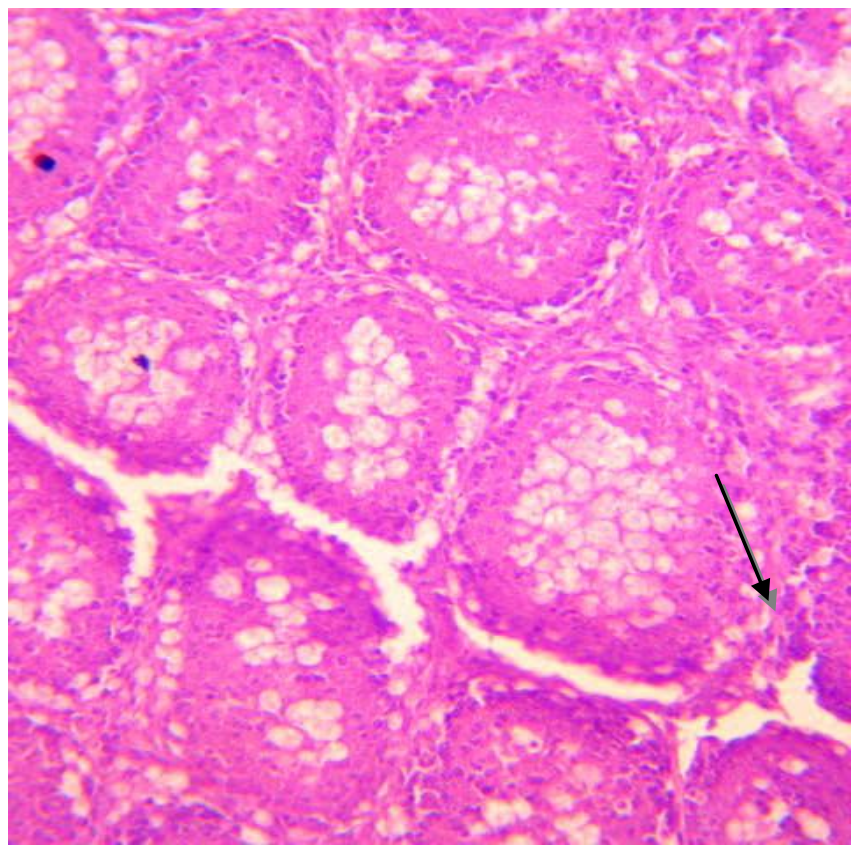

Plate 3: Bursal sections of bursa at 14 days age showing: Vacculation of medullary cells and necrosis in cortical cells (Lesion score: 3 ) X200.stained with H\&E. 


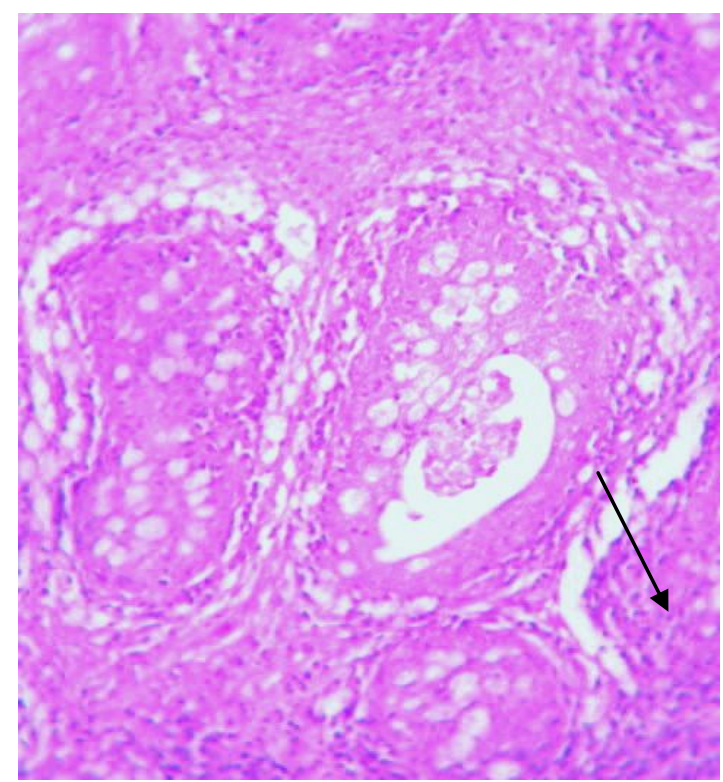

Plate 4: Bursal sections of bursa at 37 days age showing: Severe lymphocytic depletion and necrosis (arrow) and medulla of lymphoid follicles showed vacuolated reticular cells cyst formation (Lesion score: 5) X200.stained with H\&E:

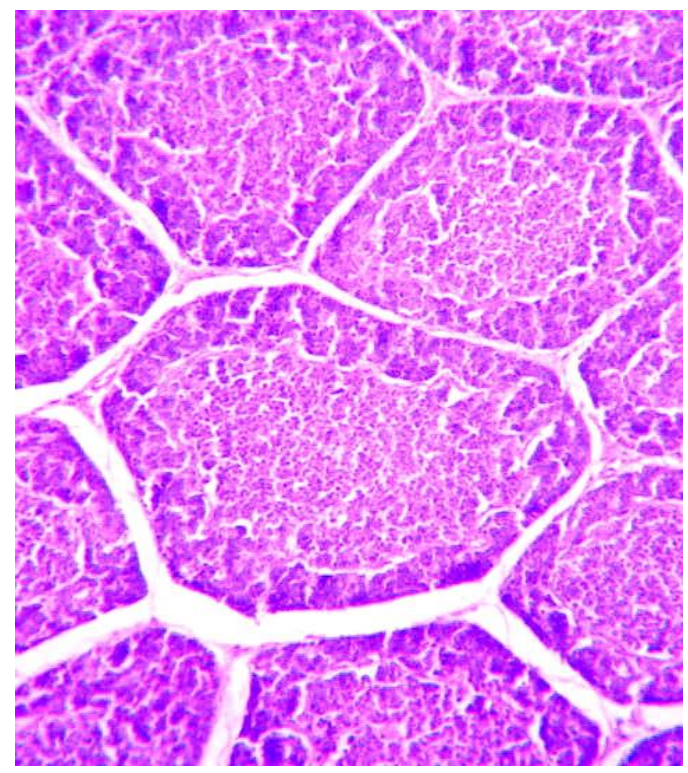

Plate 5: Normal control bursae 
The present work was carried out to find out the reliable information related with actual status of prevalence and pathological lesions of subclinical infectious bursal disease (IBD) in broiler in BeniSuef and El Mina Governorates In this study the diagnosis of IBD was made on the basis of the farm history and gross pathological lesions as had been diagnosed by Raj et al. (2009). Khan et al. (2009) reported that IBD affected birds were four weeks old conclusively. Rajaonarison et al. (2006) showed that the birds of three to five weeks of old were most susceptible to IBD. In the present study the most affected birds were four weeks old which is similar to that of Khan (2009). Richard and Miles (2004); Butcher (2003); Savova and Liupkel (2002) showed that subclinical form of IBD in chicken took placed in less than three weeks of age. In the present study no subclinical form was examined in two weeks of old Broilers. The decrease of antibody titers at 14 days of age which explain why the flocks suffer from subclinical infection and presence of bursal lesion and immunosuppression although of the presence of maternal antibodies and suggested that the existing vaccination programs were not effective. This data also suggests that viruses continue to change and may circumvent the immune system of birds despite their vaccination against IBD (Müller et al., 2003). This study revealed that immunosuppression although of the presence of maternal antibodies due to un uniformly vaccination of the breeder and that will give chance for other infections as infection with chicken infectious anemia and Ecoli infection

\section{REFERANCES}

Ahmed, Z. and Akhter, S. (2003): Role of maternal antibodies in protection against infectious bursal disease in commercial broilers. Int. J. Poult. Sci., 2: 251-255.

Bumstead, N.; Millard, B.J.; Barrow, B.A.; Cook, J.K.A. (1991): The genetic basis of disease resistance in chickens. In: Owan, J.B., Axford, R.P.E. (Eds.), Breeding for Disease Resistance in Farm Animals. CAB Int, Wallingford, England, pp. 10-23.

Butcher (2003): Pathogenesis of IBD in commercial broiler flock. IFAS, Florida, 32611.

Corley, M.M.; Giambrone, J.J. and Dormitorio, T.V. (2002): Evaluation of the immune response and detection of infectious bursal disease viruses by reverse transcriptase-polymerase chain 
reaction and enzyme-linked immunosorbent assay after in ovo vaccination of commercial broilers. Avian Dis. 46: 803-809.

Culling, C.F.A. (1974): Handbook of histological and histochemical techniques.3rd Ed., Redwood Burnld, Trowbridge and Esher. Great Britain.

Fahey, K.J.; Erny, K.M. and Crooks, J. (1989): A conformational immunogen on VP2 of infectious bursal disease virus that induces virus-neutralizing antibodies that passively protect chickens. Journal of General Virology 70: 1473-1481.

Hassan, M.K.; Afify, M.A. and Aly, M.M. (2004): Genetic resistance of Egyptian chickens to infectious bursal disease and Newcastle disease. Trop. Anim. Health Prod. 36: 1-9.

Hirai, K.; Funakoshi, T.; Nakai, T. and Shimakura, S. (1981): Sequential changes in the number of surface immunoglobulinbearing B lymphocytes in infectious bursal disease virus-infected chickens. Avian Dis., 25: 484-496.

Khan, R.W.; Khan, F.A.; Farid, K.; Khan, I. and Tariq, M. (January 2009): Prevalence of Infectious Bursal Disease in Broiler in District Peshawar.ARPN Journal of Agricultural and Biological science. $4,1$.

Kibenge, F.S.; Dhillon, A.S. and Russell, R.G. (1988): Biochemistry and immunology of infectious bursal disease virus. J. Gen. Virol., 69: 1757-1775.

Lasher, H.N. and Shane, S.M. (1994): Infectious bursal disease World's Poult. Sci., 50: 133-166.

Lucio, B. and Hitchner, S.B. (1979): Infectious bursal disease emulsified vaccine: Effect upon neutralizing antibody levels in the dam and subsequent protection of the progeny. Avian Dis., 23: (2): 466-478.

Lukert, P.D. and Saif, Y.M. (1997): Infectious bursal disease. In: Calnek, Barnes, B.W.; Beard, B.W.; McDougald, C.W.; L.R., Saif, Y.M. (Eds.), Diseases of Poultry. 10th ed. Iowa State University Press, Ames, pp. 721-738.

Muller, H.; Islam, M.R. and Raue, R. (2003): Research on infectious bursal disease- the past, the present and the future. Vet. Microbiol., 97: 153-165.

Muskett, JC.; Hopkins, L.G.; Edwards, K. and Thornton, D.H. (1979): Comparison of two infectious bursal disease vaccine strains: Efficacy and potential hazards in susceptible and maternally immune birds. The Veterinary Record; 14: 332-4. 
Rajaonarison, J.J.; Rakotonindrina, S.M.; Rakotondramary, E.K. and Razafimanjary, S. (2006): Gumboro Disease (Infectious bursitis) in Madagascar. Rev. Elev. Med. Vet. Pays Trop. 47(1):15-17.

Raj, W.K.; Farhan, A.K.; Kamran, F.; Izhar, K. and Muhammad, T. (2009): Prevalence of infectious bursal disease in broiler in district peshawar. arpn journal of agricultural and biological science. 4: 1, January 2009.

Richard and Miles (2004): Department of Dairy and Poultry Science, Cooperative Extension Service, IFAS, University of Florida, Gainesville-32616.

Savova, M. and Liupkel, V. (2002): Asymptomatic course of infectious bursitis in Chicks. Vet. Med. Nauki. 21(10): 95-101.

Sharma, J.M.; Dohms, J.E. and Metz, A.L. (1989): Comparative pathogenesis of serotype 1 and variant serotype 1 isolates of infectious bursal disease virus and their effect on humoral and immune competence of specific-pathogen-free chickens. Avian Dis 33: $112-124$.

Sharma, J.M.; Kim, I.J.; Rautenschlein, S. and Yeh, H.Y. (2000): Infectious bursal disease virus of chickens: Pathogenesis and immunosuppression. Dev. Comp. Immunol., 24: 223-235.

Steel, R.G.D. and Torrie, J.H. (1960): Principles and procedures of statistics. McGraw-Hill Book Comp. Inc. New York, Toronto, London, pp. 99-131.

Uddin, S.N. and Hossain, S.A. (2006): Effect of infectious bursal disease virus on in vitro propagation of chicken embryo fibroblast cells. AJAVA 1: 55-59.

Wit, J.J. and William Baxendale (2004): The Infectious bursal diseses.Website www.gumboro.com@Intervet 2004.

Yunis, R.; Ben-David, A.; Heller, E.D. and Cahaner, A. (2002): Genetic and phenotypic correlations between antibody responses to Escherichia coli, Infectious bursa disease virus IBDV), and Newcastle disease virus NDV), in broiler lines selected on antibody response to Escherichia coli. Poult. Sci. 81: 302-308. 